\title{
Mammals in the vicinity of Rogów (central Poland)
}

\author{
Jakub GRYZ*, Dagny KRAUZE-GRYZ** and Grzegorz LESIŃSKI*** \\ *Department of Forest Ecology, Forest Research Institute, Sekocin Stary, Braci Leśnej 3, 05-090 Raszyn, Poland; e- \\ mail:J.Gryz@ibles.waw.pl \\ **Department of Forest Zoology and Wildlife Management, Warsaw University of Life Sciences - SGGW, \\ Nowoursynowska 159, 02-776 Warsaw; e-mail: Dagny.Krauze@wl.sggw.waw.pl \\ ***Department of Functional Food and Commodity, Warsaw University of Life Sciences - SGGW, Nowoursynowska \\ 159C,02-776Warsaw; e-mail: glesinski@wp.pl
}

\begin{abstract}
The aim of the study was the inventory of mammals in the vicinity of Rogow. In the years 2000-2011 most of the standard methods for such explorations were used (i.e. live-trapping, pellet analyses, tracking). Additionally, literature data, as well as unpublished data, were analysed. Another source of information was the collection of mounted mammals of Forest and Wood Museum in Rogów. Altogether, 51 mammals from 7 orders were recorded. This included 7 alien species (muskrat, brown rat, eastern house mouse, rabbit, American mink, raccoon dog, fallow deer). Another two species were anthropogenic predators (domestic cat and dog). Abundance trends analyses were done for the selected species i.e. brown hare, rabbit, common hamster and red deer numbers decreased while beaver, wild boar, red fox and raccoon dog increased. In XXI century only one species from the Polish Red Data Book of Animals was recorded (Leisler's bat). Another important information was the record of the most northern present locality of common hamster in Poland
\end{abstract}

Key words: Mammalia, species composition, historical changes, mosaic landscape, central Poland

\section{INTRODUCTION}

Faunistic studies of mammals in Poland have decelerated in the past decades. The last comprehensive study was "Atlas of Polish mammals" by Pucek \& Raczyński (eds) published in 1983. Since then significant changes in species composition have occurred. i.e. abundance of some increased (e.g. red fox Vulpes vulpes) while the number of others plummeted (e.g. brown hare Lepus europaeus). Complex faunistic studies are carried mainly in protected areas. i.e. national parks but regional studies for the areas of lower nature value are quite rare. As forests in the vicinity of Rogów are managed as a part of the Forest Experimental Station by Warsaw University of Life Sciences - SGGW, studies on mammals of this area have been conducted since at least 1940s. Some of the results were published or included into diploma theses. and considerable amount of the information remains in the form of unpublished notes of the researchers working in the area or observations of local foresters and hunters. Yet, there is no concise work that contains and summarizes all the accessible knowledge about mammals of the area in question.

As a result, our goal was to gather all the published and unpublished information about the theriofauna, to complement this with the authors' results from the last years (2000-2011) and to show, in selected species, changes in their numbers throughout decades.

\section{MATERIAL AND METHODS}

The study was conducted in the vicinity of Rogów (UTM coordinates: DC 14. 23. 24. 33) in the area that encompassed around $110 \mathrm{~km}^{2}$ of a mosaic of woodlands $(23 \%)$, arable lands $(59 \%)$, grasslands $(5 \%)$, and orchards $(5 \%)$ with small towns, villages and fallow land being 
the remaining part. There are also two fish ponds (Byliny pond, close by Lochów village, $51^{\circ} 44^{\prime} 20.41^{\prime \prime} \mathrm{N}, 20^{\circ} 06^{\prime} 12.61^{\prime \prime} \mathrm{E}$; Popień pond, $51^{\circ} 47^{\prime} 02.36^{\prime \prime} \mathrm{N}, 1^{\circ} 55^{\prime} 35.03^{\prime \prime} \mathrm{E}$ ) and three rivers (Rawka, Mroga and Lupia) within the area (Fig. 1). Game is managed within three hunting districts $(99,122,143)$, belonging to the Forest Experimental Station in Rogów. Most of the forests (excluding Kolacin, no. 7, Fig. 1), referred to in this study, are in the management of the Experimental Forest District. Mixed deciduous and fresh deciduous forests are the dominant forest site types, with the prevalent species being Scots pine Pinus sylvestris, oaks Quercus spp. and an admixture of European larch Larix decidua and beech Fagus silvatica. The study area is described in detail by Zielony (1993).

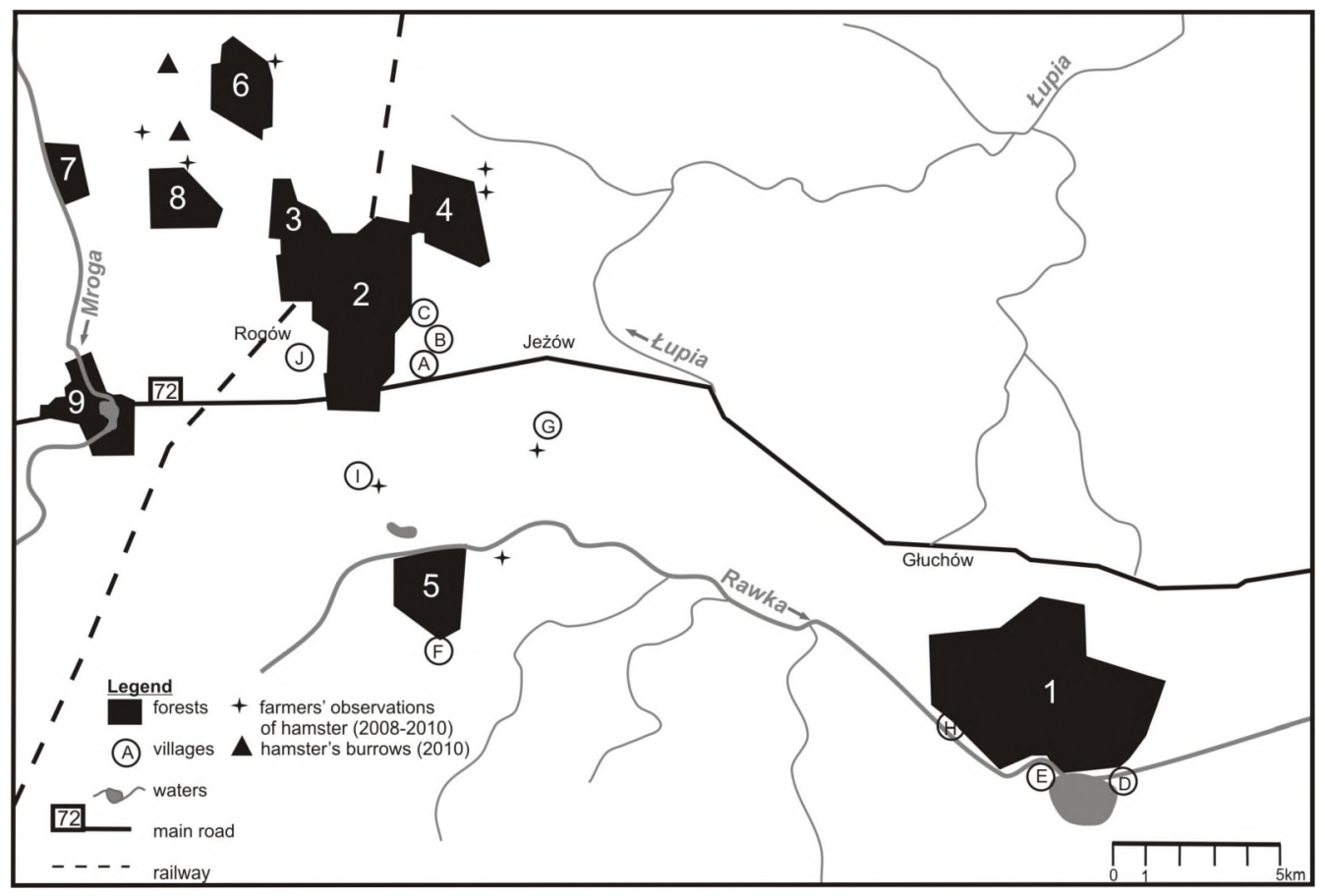

Fig. 1. Distribution of the forests and villages in the study area: 1 - Gluchów (968.5 ha), 2 - Zimna Woda \& Wilczy Dół (449.5 ha), 3 - Doliska (202.3 ha), 4 - Górki (206.98 ha), 5 - Popień (168.3 ha), 6 - Zacywilki (166.4 ha), 7 Kołacin (60.0 ha), 8 - Jasien (134.1 ha), 9 - Rogów (168.93 ha); A - Strzelna, B - Jasienin Mały, C - Jasienin Duży, D - Stare Byliny, E - Lochów, F - Wola Lokotowa, G - Kosiska, H - Wola Naropińska, I - Popień, J - Marianów Rogowski. Areas of the forests according to Zaręba (1993).

Between 2000 and 2011 most of the standard methods were used for faunistic explorations. Those included:

1. Live-trapping of rodents in box-traps. A hundred traps were distributed in the arable land (west of Zimna Woda \& Wilczy Dół forest: $51^{\circ} 48^{\prime} 52.00^{\prime \prime} \mathrm{N}, 19^{\circ} 54^{\prime} 03.31^{\prime \prime} \mathrm{E}$ ) and in the woodland (Zimna Woda \& Wilczy Dól: $51^{\circ} 49^{\prime} 26.26^{\prime \prime} \mathrm{N}, 19^{\circ} 533^{\prime} 58.92^{\prime \prime}$, Górki: $51^{\circ} 50^{\prime} 15.62^{\prime \prime} \mathrm{N}$, $19^{\circ} 55^{\prime} 51.61^{\prime \prime E}$ ). Trapping was conducted in June, August, October 2007 and April 2008 for three consecutive days.

2. Analyses of pellets of diurnal raptors: common buzzard (Krauze 2003), goshawk (Gryz 2003), and owls: tawny owl (Gryz 2009, J. Gryz, unpbl.), long-eared owl (1,636 prey items, J. Gryz \& D. Krauze-Gryz, unpubl.). 
3. Analyses of scats and guts of predators: cats (Krauze 2008) and stray dogs (260 scats, D. Krauze-Gryz \& J. Gryz, unpbl.).

4. Bat netting over waters ( 1 site - the Mroga river) or on the forest lanes ( 9 sites: Gluchów - 1, Górki - 1, Zimna Woda - 6, Doliska - 1), monitoring of bat roosts: nurseries (buildings, boxes) and hibernating sites (village cellars).

5. Snow tracking (tracking platforms were also used, Krauze 2008).

6. Monthly spot-light counts on regular routes (Krauze 2008).

7. Monitoring of mortality of mammals on the roads crossing the study area (Lesiński et al. 2009).

8. Door-to-door survey (211 respondents), carried out in 24 villages around study area in summer and autumn 2010, aimed at defining places of possible hamster presence.

Results of drive censuses, that were conducted by students during field training, were taken from the Department of Forest Zoology and Wildlife Management, Warsaw University of Life Sciences - SGGW. Data on the hunting bag was gathered from the Forest Experimental Station in Rogów. Mounted mammals, originating from the area, and collected in the local Forest and Wood Museum were another source of information (referred to thereafter as Museum collection). Species determination of the Museum collection was verified by authors. Finally, published data and diploma theses were reviewed, and unpublished information (from the researchers, foresters, hunters, and inhabitants) was collected.

\section{RESULTS}

Altogether, 53 species were recorded in the study area and they belonged to 7 orders: Erinaceomorpha - 1 species, Soricomorpha - 4 sp., Chiroptera - 13 sp., Lagomorpha - 2 sp., Rodentia - 16 sp., Carnivora - 12 sp., and Cetartiodactyla - 5 sp. (Table 1).

\section{Erinaceomorpha}

No studies of hedgehog Erinaceus roumanicus were conducted in the area. Two specimens of this species, that come from the area, are exposed in the Museum. They date from 26.05.1955 (Popień) and 30.04.1968 (Doliska). Hedgehogs were also observed directly:

- 05.2001, north of Gluchów forest,

- 08.2002, north-west of Popień forest, a road-kill,

- 09.2005, area of Doliska forest,

- 06.2009 near the Forest and Wood Museum.

Finally, tracks (Erinaceus sp.) were seen in July 2002 in the south of Gluchów forest.

\section{Soricomorpha}

The latest information on the representatives of this order was gathered indirectly by raptors' diet analyses.

European mole Talpa europaea was commonly noted in the diet of common buzzard where it formed between 12 (Krauze 2003) to 14\% (Goszczyński 1991) of consumed prey items. It was found less frequently in the diet of tawny owl (1.2\%, Gryz 2009) and was also trapped in pitfall traps (Aulak 1971).

The other three species registered were: common shrew Sorex araneus, pygmy shrew Sorex minutus and water shrew Neomys fodiens. The first species was caught by tawny owl $(1.8 \%$ of all the vertebrate prey items, Gryz 2009), long-eared owl (J. Gryz \& D. Krauze-Gryz, unpubl.) as well as by common buzzard (Krauze 2003). Pygmy shrew and water shrew were recorded in the diet of tawny owl (0.3 and $0.1 \%$ of vertebrate prey items, respectively, Gryz 2009). For water shrew it was the only record from the area: one individual was found in the pellet 
collected in October 2006 in the south of Popien forest, near the Rawka river $\left(51^{\circ} 46^{\prime} 46.68^{\prime}\right.$ 'N, $19^{\circ} 56^{\prime} 01.23^{\prime}$ 'E). Pygmy shrew was commonly (i.e. twice as often as S. araneus) found in pitfall traps (Aulak 1971). Moreover, one specimen is a part of the Museum collection (Wilczy Dó1, 20.07.1968 - leg. S. Zaborowski).

Table 1 . The list of mammals registered in the vicinity of Rogów

\begin{tabular}{|c|c|c|}
\hline No & Species & UTM (DC) \\
\hline 1 & $\begin{array}{c}\text { Erinaceomorpha } \\
\text { European hedgehog Erinaceus roumanicus Berret-Hamilton, } 1900\end{array}$ & $14,23,24,33$ \\
\hline $\begin{array}{l}2 \\
3 \\
4 \\
5\end{array}$ & $\begin{array}{l}\text { Coricomorpha } \\
\text { Common shrew Sorex araneus Linnaeus, } 1758 \\
\text { Pygmy shrew Sorex minutus Linnaeus, } 1766 \\
\text { Water shrew Neomys fodiens Pennant, } 1771 \\
\text { Common mole Talpa europaea Linnaeus, } 1758\end{array}$ & $\begin{array}{l}14,23,24,33 \\
23,24,33 \\
23 \\
14,23,24,33\end{array}$ \\
\hline $\begin{array}{c}6 \\
7 \\
8 \\
9 \\
10 \\
11 \\
12 \\
13 \\
14 \\
15 \\
16 \\
17 \\
18 \\
\end{array}$ & $\begin{array}{l}\text { Chiroptera } \\
\text { Large mouse-eared bat Myotis myotis (Borkhausen, 1797) } \\
\text { Brandt's bat Myotis brandtii (Eversmann, 1845) } \\
\text { Whiskered bat Myotis mystacinus (Kuhl, 1817) } \\
\text { Daubenton's bat Myotis daubentonii (Kuhl, 1817) } \\
\text { Parti-coloured bat Vespertilio murinus Linnaeus, } 1758 \\
\text { Serotine Eptesicus serotinus (Schreber, 1774) } \\
\text { Leisler's bat Nyctalus leisleri (Kuhl, 1817) } \\
\text { Noctule Nyctalus noctula (Schreber, 1774) } \\
\text { Nathusius' pipistrelle Pipistrellus nathusii (Keyserling \& Blasius, 1839) } \\
\text { Soprano pipistrelle Pipistrellus pygmaeus (Leach, 1825) } \\
\text { Brown long-eared bat Plecotus auritus (Linnaeus, 1758) } \\
\text { Grey long-eared bat Plecotus austriacus (Fischer, 1829) } \\
\text { Barbastelle Barbastella barbastellus (Schreber, 1774) }\end{array}$ & $\begin{array}{l}33 \\
24,33 \\
24 \\
24 \\
24 \\
24,33 \\
24,33 \\
14,24,33 \\
24 \\
33 \\
24,33 \\
24 \\
24\end{array}$ \\
\hline $\begin{array}{l}19 \\
20\end{array}$ & $\begin{array}{l}\text { Lagomorpha } \\
\text { Brown hare Lepus europaeus Pallas, } 1778 \\
\text { Rabbit Oryctolagus cuniculus (Linnaeus, 1758) }\end{array}$ & $\begin{array}{l}14,23,24,33 \\
23,24,33\end{array}$ \\
\hline $\begin{array}{l}21 \\
22 \\
23 \\
24 \\
25 \\
26 \\
27 \\
28 \\
29 \\
30 \\
31 \\
32 \\
33 \\
34 \\
35 \\
36 \\
\end{array}$ & 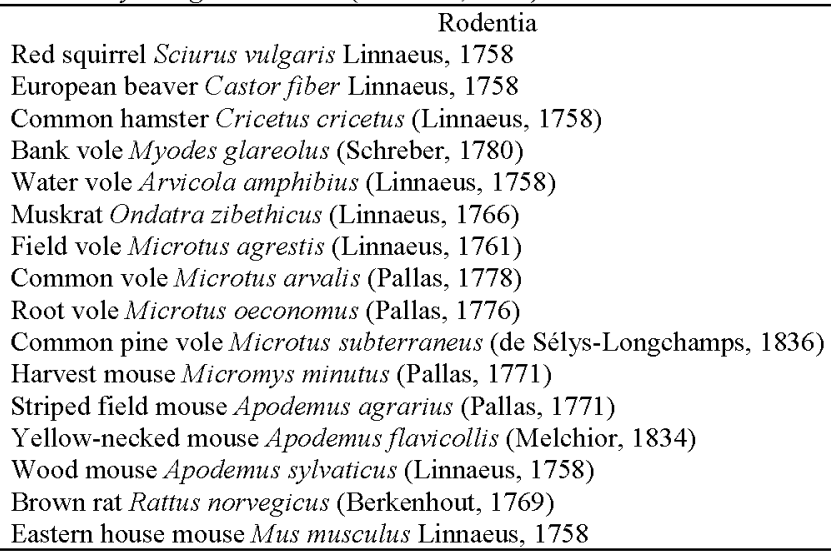 & $\begin{array}{l}14,23,24,33 \\
14,23,24,33 \\
23,24 \\
14,23,24,33 \\
23,33 \\
14,24,33 \\
24,33 \\
14,23,24,33 \\
23,24,33 \\
24,33 \\
23,24 \\
14,23,24,33 \\
14,23,24,33 \\
24,33 \\
23,24,33 \\
24,33\end{array}$ \\
\hline $\begin{array}{l}37 \\
38 \\
39 \\
40 \\
41 \\
42 \\
43 \\
44 \\
45 \\
46\end{array}$ & \begin{tabular}{l}
\multicolumn{1}{c}{ Carnivora } \\
Red fox Vulpes vulpes (Linnaeus, 1758) \\
Raccoon dog Nyctereutes procyonoides (Gray, 1834) \\
Stoat Mustela erminea Linnaeus, 1758 \\
Weasel Mustela nivalis Linnaeus, 1766 \\
Western polecat Mustela putorius Linnaeus, 1758 \\
American mink Neovison vison (Schreber, 1777) \\
Stone marten Martes foina (Erxleben, 1777) \\
Pine marten Martes martes (Linnaeus, 1758) \\
Badger Meles meles (Linnaeus, 1758) \\
Otter Lutra lutra (Linnaeus, 1758)
\end{tabular} & $\begin{array}{l}14,23,24,33 \\
14,23,24,33 \\
24 \\
14,23,24,33 \\
23,24,33 \\
14,23,33 \\
14,23,24,33 \\
14,23,24,33 \\
14,23,24,33 \\
14,23,24,33\end{array}$ \\
\hline
\end{tabular}




\begin{tabular}{|l|l|l|}
\hline \multicolumn{1}{|c|}{ Cetartiodactyla } & $14,23,24,33$ \\
47 & Wild boar Sus scrofa Linnaeus, 1758 & 24,33 \\
49 & Fallow deer Dama dama (Linnaeus, 1758) & $14,23,24,33$ \\
50 & Red deer Cervus elaphus Linnaeus, 1758 & $14,23,24,33$ \\
51 & Elk Alces alces (Linnaeus, 1758) & $14,23,24,33$ \\
\hline & Roe deer Capreolus capreolus (Linnaeus, 1758) & $14,23,24,33$ \\
52 & Domestic dog Canis lupus f. familiaris & $14,23,24,33$ \\
53 & Domestic cat Felis sylvestris f. catus & \\
\hline
\end{tabular}

\section{Chiroptera}

All the methods of bat detection that were used in the period of 2006-2009, together with the Museum collection and published data (Kowalski \& Lesiński 1994, Lesiński et al. 2009), derived information on 13 species. The most common were: serotines, noctules and brown long-eared bats (Table 2).

Table 2. Bats in the vicinity of Rogów; L - literature (Kowalski \& Lesiński 1994), M - museum collection, N netting, $\mathrm{R}$ - road kill (Lesiński et al. 2009), $\mathrm{H}$ - hibernating sites, $\mathrm{S}$ - summer roosts, $\mathrm{P}$ - pellets, $\mathrm{O}$ - other; $\mathrm{r}-$ rare, sr - semi-rare, c-common, ? - data deficient; *-M. mystacinus or $M$. branditi

\begin{tabular}{|r|l|c|c|}
\hline $\mathrm{Nr}$ & Species & Method of detection & $\begin{array}{c}\text { Frequency } \\
\text { estimate }\end{array}$ \\
\hline 1 & Myotis myotis & $\mathrm{L}, \mathrm{M}$ & $?$ \\
2 & Myotis brandtii & $\mathrm{L}, \mathrm{M}, \mathrm{N}$ & $\mathrm{r}$ \\
3 & Myotis mystacinus & $\mathrm{L}, \mathrm{N}$ & $\mathrm{r}$ \\
4 & Myotis daubentonit & $\mathrm{N}, \mathrm{R}$ & $\mathrm{sr}$ \\
5 & Vespertilio murinus & $\mathrm{M}$ & $?$ \\
6 & Eptesicus serotinus & $\mathrm{M}, \mathrm{N}, \mathrm{S}$ & $\mathrm{c}$ \\
7 & Nyctalus noctula & $\mathrm{L}, \mathrm{M}, \mathrm{N}, \mathrm{R}$ & $\mathrm{c}$ \\
8 & Nyctalus leisleri & $\mathrm{L}, \mathrm{M}, \mathrm{N}$ & $\mathrm{r}$ \\
9 & Pipistrellus nathusii & $\mathrm{N}, \mathrm{R}$ & $\mathrm{sr}$ \\
10 & Pipistrellus pygmaeus & $\mathrm{M}$ & $?$ \\
11 & Plecotus auritus & $\mathrm{L}, \mathrm{M}, \mathrm{N}, \mathrm{H}, \mathrm{S}, \mathrm{O}, \mathrm{P}, \mathrm{R}$ & $\mathrm{c}$ \\
12 & Plecotus austriacus & $\mathrm{H}$ & $?$ \\
13 & Barbastella barbastellus & $\mathrm{M}, \mathrm{N}, \mathrm{R}$ & sr \\
\hline
\end{tabular}

Large mouse-eared bat Myotis myotis was found in boxes (Kowalski \& Lesiński 1994). Moreover, there is $1{ }^{\star}$ in the Museum collection (22.08.1966, Gluchów). Its presence was not confirmed in the last decade. Though, it probably still occurs in this area but is rare.

Whiskered bat Myotis mystacinus and Brandt's bat Myotis brandtii belong to rare and not abundant species. Due to the fact that for many years they were not distinguished, older data from boxes (Kowalski \& Lesiński 1994) could concern either of these species. The presence of Brandt's bat was confirmed by netting ( $1 \hat{\mathrm{ad}}$., 19 juv. - 17.07.2007) in Zimna Woda, and whiskered bat over the Mroga river ( $19 \mathrm{ad}$ - 09.07.2009). One female collected by S. Zaborowski on 27.07.1966 in Gluchów forest (Museum collection) was determined as Brandt's bat.

Daubenton's bat Myotis daubentonii in areas with many water reservoirs (western part of the study area - the Mroga river valley) is probably common and numerous. Adult females with signs of lactation were caught on 12.07 .2006 ( 7 ind.) and 09.07.2009 (9 ind.). Three juvenile individuals were also killed by vehicles on the road crossing Rogów forest: ( 2 ind. 09.07.2009, 1 ind. - 09.08.2009, Lesiński et al. 2009).

Only one record of parti-coloured bat Vespertilio murinus is known from the study area ( $1 \delta$ in the Museum collection, 29.07.1950 - leg. S. Smólski). Serotine Eptesicus serotinus was frequently netted in Gluchów ( 8 우 ad., $3 \hat{\delta} \widehat{\partial}$ ad. - 16.07.2007), Zimna Woda \& Wilczy Dól 
(e.g. $10 q q$ ad., $4 \hat{\delta}$ ad., $1 q$ juv. - 16.07.2007) and Doliska (1q ad. - 10.07.2006) forests. Dead individual of this species was also found in July 2007 in the attic of the forester lodge in Gluchów.

Noctule Nyctalus noctula was netted in Rogów (1q juv. - 12.07.2006) and Gluchów (1q juv. $-16.07 .2007)$ forests and found as road kills ( 2 ind. $-03.09 .2008,1$ ind $-09.08 .2009,2$ ind. -10.09 .2009 ) in Rogów forest (Lesiński et al. 2009). Flying noctules were observed and recorded by detectors at several sites in Zimna Woda \& Wilczy Dól and Doliska forests. Finally, its breeding colony in a an oak hollow was detected on 22.06.2010 in Rogów forest. Relatively rarely noted Leisler's bat Nyctalus leisleri was found twice - one specimen preserved in the Museum collection (1 , Gluchów, 25.05.1966 - leg. S. Zaborowski) and adult female netted over the Mroga River on 12.07.2006.

Bats from the genus Pipistrellus are represented by two species: Nathusius' pipistrelle $P$. nathusii and soprano pipistrelle $P$. pygmaeus. The first was netted in Doliska on 10.07.2006 ( $1 \hat{\delta}$ ad.) and was found as a road kill near the Mroga River Valley (03.09.2008, Lesiński et al. 2009), the latter occurs in the Museum collection (1+, Gluchów, 03.09.1969 - leg. S. Zaborowski).

Brown long-eared bat Plecotus auritus was recorded with the aid of various methods. It was netted quite frequently on the forest lanes in Zimna Woda \& Wilczy Dól and Gluchów forests. It occupied boxes ( 1 ind. 15.07.2007, Zimna Woda \& Wilczy Dól) and hibernated in small cellars (on 27.12.2007 in villages: Jasien - 1 ind., Rogów - 1 ind., Przylęk Duży - 2 ind.). S. Zaborowski found 19 in Strzelna (15.08.1968). One dead individual was found on the road in Rogów forest (10.09.2009, Lesiński et al. 2009), another one in the forester lodge in Gluchów (07.2007). Grey long-eared bat Plecotus austriacus seems to be rarer - its presence was confirmed only once (an individual during hibernation on 27.12.2007 in small cellar at the edge of Zimna Woda \& Wilczy Dól forest). Three localities of barbastelle Barbastella barbastellus are known: two in Zimna Woda \& Wilczy Dól forest - 2 q 9 ad. netted (17.07.2007) and a road casualty (03.09.2008, Lesiński et al. 2009), and one in Strzelna (1ð collected by M. Stuglik, 27.09.1955).

\section{Lagomorpha}

Brown hare, similarly to most of the European countries (Smith et al. 2005), is in a severe decline (Gryz \& Krauze 2007). According to the last spot-light count (06-08.11.2009) autumn density was 2 ind./100 ha (D. Krauze-Gryz \& J. Gryz, unpublished). Therefore, yearly hunting bag of this species is a few (less than 10) individuals.

As far as European rabbit Oryctolagus cuniculus is concerned, no colonies are known these days. In the first half of 1990 s at least five vital colonies were known. They were located near Głuchów, Popień and Górki forest complexes and around sawmill in Rogów village (D. Dałkowski, G. Kowalski, M. Wasilewski, pers. inf.). The last observation comes from 2007, when 4 individuals were seen near Wola Lokotowa village (D. Dałkowski, pers. inf.). There are also two Museum specimens that come from the area of Doliska forest (09.12.1949 and 09.01.1950 - leg. M. Stuglik).

\section{Rodentia}

Six species were recorded during live-trapping sessions (Table 3), with yellow-necked mouse Apodemus flavicollis being the most common in the forest and striped field mouse $A$. agrarius in the arable land. According to earlier studies (based on pitfall traps, Kurzyna 1982) done in the same forest complex (Górki forest) bank vole Myodes glareolus was more numerous than yellow-necked mouse. Root vole Microtus oeconomus was recorded in the 
pitfall traps (Aulak 1971, Kurzyna 1982) as well as in the box-traps (Zimna Woda \& Wilczy Dól, forest complex, Gryz 2009, J. Gryz, unpubl.). Under investigations by Aulak (1971) field vole Microtus agrestis, common pine vole Microtus subterraneus as well as harvest mouse Micromys minutus were also recorded. Field vole seems to be very rare or ephemeral in the study area. After Aulak (1971), it was recorded only one more time by Juszko (2005) in the diet of long-eared owl ( 1 ind.). Common pine vole on the other hand was recorded in the diet of predators: foxes and martens (Goszczyński 1986), cats (3 ind., the area of Zimna Woda forest), common buzzard ( 1 ind. from Gluchów forest, Krauze 2003), and in the diet of tawny owl (2 ind., Zimna Woda and Górki forests, Osowiecka 2008). There is also one specimen of this species in the Museum (Stare Byliny, 12.03.1967 - leg. S. Zaborowski). Harvest mouse was found in the diet of tawny owl (Gryz 2009).

Table 3. Small rodents' assemblage on the basis of live-trapping. Trapping sites were located near Rogów village. Three-days trapping sessions in VI, VIII, X. 2007 and IV. 2008.

\begin{tabular}{|c|c|c|c|c|c|}
\hline \multirow{2}{*}{ No } & \multirow{2}{*}{ Species } & \multicolumn{2}{|c|}{ Forest site } & \multicolumn{2}{|c|}{ Field site } \\
\hline & & $\mathrm{N}$ of captures & $\%$ of all captures & N of captures & $\%$ of all captures \\
\hline 1 & Myodes glareolus & 26 & 26.3 & \multirow{3}{*}{20} & \multirow{3}{*}{17.4} \\
\hline 2 & Apodemus flavicollis & 52 & 52.5 & & \\
\hline 3 & Apodemus sylvaticus & 4 & 4.0 & & \\
\hline 4 & Apodemus agrarius & \multirow[t]{3}{*}{17} & \multirow[t]{3}{*}{17.2} & 85 & 73.9 \\
\hline 5 & Microtus arvalis & & & 3 & 2.6 \\
\hline 6 & Mus musculus & & & 7 & 6.1 \\
\hline \multirow{2}{*}{\multicolumn{2}{|c|}{$\begin{array}{r}\text { Total } \\
\text { Number of controls }\end{array}$}} & 99 & 100 & 115 & 100 \\
\hline & & \multicolumn{2}{|c|}{940} & \multicolumn{2}{|c|}{840} \\
\hline
\end{tabular}

In the owl's diet, common vole Microtus arvalis was the most numerous species of open areas and yellow-necked mouse forest species (Gryz 2009, J. Gryz \& D. Krauze-Gryz, unpbl.). Apart from being present in the open arable land, common vole was also trapped in the forest (i.e. Zimna Woda \& Wilczy Dó1, Gluchów), on small food plots for game (Gryz \& Krauze 2007). Analyses of owl pellets showed presence of brown rat Rattus norvegicus (Gryz 2009), which was also recorded from the diet of fox and common buzzard (Juszko 2005).

Water vole Arvicola amphibius was found in 2002 ( 2 ind., Gluchów forest, $51^{\circ} 45^{\prime} 00.63$ ' $N$, $20^{\circ} 04 ' 51.87^{\prime}$ ' $\mathrm{E}$ ) and on 10.04.2011 (1 ind., Popień forest) in the pellets of tawny owl collected near the Rawka river.

There is not much actual information about muskrat Ondatra zibethicus: it has not been hunted for at least 10 years (data from the Experimental Forest Station). Previously, in the 1980s, it was present at the Rawka river, along the drainage ditches near Popien forest, at the water flows in the vicinity of Zimna Woda \& Wilczy Dól (close by Jasienin Maly village) and at Byliny ponds (M. Wasilewski, pers. comm.). One specimen in the Museum is dated from 09.10.1967 (Strzelna - leg. S. Zaborowski) and lately (in July 2005) its remains were found at the Mroga river (Kolacin forest). According to the staff of Byliny fish ponds, muskrats were seen there in July 2008.

No attempts to assess red squirrel Sciurus vulgaris abundance were made. However, its tracks, as well as feeding remains are found in all the forests. There is also one specimen in the Museum (Gluchów, 26.01.1950 - leg. M. Stuglik). It was found in the diet of fox and martens (Goszczyński 1986), goshawk (Krauze et al. 2005) as well as common buzzard (Juszko 2005). Two nests of squirrel were found in spring 2007 in the boxes set for tawny owls: in Górki forest (D-type nest box) and in Gluchów forest (E-type nest box, 5 juv.) (Gryz \& Krauze-Gryz 2011). Two dreys were registered in Kolacin forest on 17.04.2011. In April and May 2011 several direct observations of squirrels (red coat) were done: 1 ind. - Gluchów , 2 ind. - 
Kolacin, 3 ind. - Doliska, 1 ind. - Popień, 1 ind. - Zimna Woda \& Wilczy Dól) and on 1.04.2011 one brown individual was seen in Górki forest.

European beaver Castor fiber reappeared in the area after its successful reintroduction to the Rawka river valley: on 16.10.1983 11 animals from Wigry lake and surrounding water bodies were released into four sites located below the study area (Doleck being the closest, Twardowski 1988). Afterwards, the species gradually colonized the whole valley (Kobojek 2005): in 1987 animals were present $20 \mathrm{~km}$ up the river in Żydomice village (Twardowski 1988). In the end of 1980 s/beginning of 1990 s first beaver was recorded in the study area: it was caught in the drainage ditch near Jeżów (D. Dalkowski, J. Goszczyński, pers. comm.). In 1998 first beavers settled in the Rawka river (south of Gluchów forest) (S. Zaborowski, unpubl.).

The time of colonization of the Mroga river is unknown, yet in May 2001 numerous signs of beavers' presence were registered at its banks. These days, activity indicators of beaver (burrows, tracks, downed trees, bark-stripped branches) are found in all the water flows in the area. One road kill was noted in Rogów forest on the bridge over the Mroga river (26.06.2009).

The information on common hamster Cricetus cricetus presence comes from several sources. Two specimens that originate from the area of villages Popień and Kosiska ( 1 juv. 01.10.1949, leg. M. Stuglik and 10 ad. -03.09 .1968 , leg. S. Zaborowski) are in the Museum collection. Then, during studies of common buzzard ecology, conducted between 1981-1990 (Goszczyński 1991), remains of 12 individuals were found in the raptors' nests (Zacywilki, Górki, Zimna Woda \& Wilczy Dół, Jasień and Popień forests, J. Goszczyński, unpubl. data). Similar studies performed 10 years later did not reveal hamster as a prey of common buzzard (Krauze 2003). Yet, it must be noted that the latter studies were less prolonged (3 years), based on far fewer prey items (812 in comparison to 4,925) and food remains were collected only from the ground below the nests, instead of directly from the inside of the nests. Information about hamster presence in the area of Popień, Zacywilki and Gluchów was also delivered by some of the local farmers (2000-2005). However, this was not checked in the field by us. Nevertheless, hamsters were recorded as prey of fox: in 2000 (Juszko 2005), and in 2002 in the area of Zacywilki (51 $51^{\prime} 14.43^{\prime}$ 'N, $19^{\circ} 52^{\prime} 57.03^{\prime}$ 'E, J. Gryz, pers. obs.). Door-to-door survey carried out in 2010 showed that common hamster is well known in the area: $25 \%$ of inhabitants have ever seen the animal and $20 \%$ its burrows, more than half of the people asked $(63 \%)$ were familiar with the name of the animal. Eight places were indicated by farmers as current (up to two years backward) localities of hamster (Fig. 1). These places will undergo more thorough search in the nearest future. Yet, so far burrows, assumingly built by the species in question, were found in October 2010 in the area of Zacywilki forest (Fig. 1). One of those was located in the open field and the other in a small sand pit. According to Ziomek and Banaszek (2007) common hamster is no longer present in the area of Rogów. It is possible, however, that its abundance is so low these days that it was not recorded under the aforementioned study.

We assumed the presence of coypu Myocaster coypus (Molina, 1782) possible. One specimen is in the Museum. However, it is devoid of any documentation so its origin remains unknown. In 1980s remains of at least 3 individuals were recorded near the fox dens (J. Goszczyński, pers. comm., Goszczyński 1995). Probably foxes utilized carcasses that were disposed of.

\section{Carnivora}

Among wild predators red fox is the most numerous. As a result of rabies vaccination significant increase in its abundance was recorded (Goszczyński et al. 2008). Between the two compared study periods (1980-1995 and 1996-2005) three density indices achieved higher 
values: snow tracking index doubled (from 5.86 to 11.01), density index based on drive censuses changed from 1.08 to 1.28 and the number of dens with cubs rose from 1.7 to 3.55 (Goszczyński et al. 2008). The hunting bag of this species is 58-72 individuals (2003-2009).

In the years 1979-1892 on average 15 dens of badgers Meles meles in all the forest complexes were recorded (Goszczyński 1985). Its density was estimated in 1995 at 2.6 ind./100 ha of forested area (Goszczyński \& Skoczyńska 1996). On the basis of sample checkouts performed on the occasion of field classes with students, badgers' distribution within the forests seems to be quite stable. These animals are harvested occasionally, no more than a few individuals per year ( 2 ind. in 2008/2009 hunting season).

The two marten species: stone Martes foina and pine marten Martes martes were recorder during winter tracking in 1978 by J. Goszczyński (unpubl.). Their presence was confirmed by molecular analyses (Posłuszny 2005, Goszczyński et al. 2007). Also, a skull of stone marten is deposited in the collection of the Department of Forest Zoology and Wildlife Management (Zacywilki, 19.07.2005 - leg. J. Gryz). In October 2006 and December 2010 pine martens were observed in the tawny owl nest boxes in Zacywilki and Gluchów forests (J. Gryz, D. KrauzeGryz, pers. obs.). Density, based on snow tracking, assessed in 2001-2002 (the two species pooled) was from 0.18 (in the open field) to 0.27 ind. $/ \mathrm{km}^{2}$ (in the forest) (Juszko 2005). Similarly to badgers, martens (Martes spp.) are sporadically hunted (i.e. 2 ind. in 2008/2009 hunting season).

Polecat Mustela putorius was never the object of ecological studies in the area. In $1995 \%$ was trapped in the culvert under railway separating Doliska and Zimna Woda \& Wilczy Dól and in the beginning of 1990 s dead polecat was found in central part of Zimna Woda \& Wilczy Dół forest (J. Goszczyński, pers. inf.). One individual was seen (authors' observation) in May 2002 in the field close to Popien fish pond. Another record comes from Łochów village, where in 2004 one animal was killed by dogs (G. Kowalski, pers. comm.). In 1979-1981 tracks of polecat were recorded in the area of Zimna Woda \& Wilczy Dól and Górki forests and again in 2003 in the south of Zimna Woda \& Wilczy Dól (J. Goszczyński, unpubl. data). Polecat's presence was then recorded during snow tracking (17.02.2008) in Popień forest, along the Rawka river - the density of tracks being $0.25(\mathrm{~N}$ tracks $/ \mathrm{km} / 24 \mathrm{~h})$.

The first information about European otter Lutra lutra is the Museum specimen (16.01.1950 leg. M. Stuglik) from the vicinity of Gluchów forest. Between 1993-1994, during national field survey (Brzeziński et al. 1996) otter was recorded in Wola Naropińska at the Rawka river (J. Romanowski, pers. inf.), locality to the south-west of Gluchów forest. Snow tracking (17.02.2008) at the Rawka river and Popień pond gave the density of tracks at the level of $1.03(\mathrm{~N}$ tracks $/ \mathrm{km} / 24 \mathrm{~h}$ ). Also, tracks of the species were seen $(30.02 .2007)$ on the frozen Byliny pond and on the small pond in Wola Naropińska village. Moreover, three dead animals were found: road kills near Jeżów (April 2005, M. Misiorowska, pers. comm.) and at Byliny pond (juv., 23.09.2008) and one individual at the Rawka river in Popień forest (October 2008).

It is not known when American mink Neovison vison colonized the area. Yet, in winter 2001/2002 its tracks were recorded at the Mroga river (Kolacin forest). These days it is present at most of the water flows. The density of its tracks (17.02.2008) was higher that in the case of polecat and otter and reached 3.03 tracks $/ \mathrm{km} / 24 \mathrm{~h}$. On 10.04 .2011 one individual was seen at the Rawka river in Popień forest (J. Gryz, pers. obs.).

Stoat Mustela erminea was observed twice in the first half of 1980s by J. Goszczyński (pers. comm.) in Zimna Woda \& Wilczy Dół forest: one was a direct observation and remnants of one individual were found in the common buzzard's nest.

Least weasel Mustela nivalis is known from the diet of buzzards and goshawks (Goszczyński \& Pilatowski 1986) as well as fox diet (Juszko 2005). It was also accidentally trapped in the rodent box trap (M. nivalis vulgaris) in the field near Zimna Woda \& Wilczy Dól 
(29.08.2007 - leg. J. Gryz, collection of the Department of Forest Zoology and Wildlife Management) and again in the same place on 1.07.2011 (Mustela nivalis nivalis). Also, its tracks were recorded on the tracking platforms (Krauze 2008) set in the arable land near Zimna Woda forest (Marianów Rogowski village) and in Górki forest ( 7 tracks/1888 controls). Osowiecka (2008) noted 0.4 tracks/km of least weasel in Zimna Woda \& Wilczy Dól forest and 2.3 tracks $/ \mathrm{km}$ in the surrounded fields.

Raccoon dog Nyctereutes procyonoides became a regular component of local theriofauna. It was probably first noted in mid-1970s when its skull was found at the fox den in the Popien reserve (J. Goszczyński, pers. comm.). These days they are frequently observed in the area, i.e. in Gluchów forest (3 juv. in July 2003, J. Gryz, D. Krauze-Gryz, pers. obs.; on 17.05.2008, P. Nasiadka, pers. comm.) or at fish ponds near Popień (5.12.2007, D. Dałkowski, pers. comm.). Also their tracks are registered, i.e. in Zimna Woda \& Wilczy Dół (October 2004), in Zacywilki forest (summer 2005, D. Krauze-Gryz, J. Gryz, pers. obs.). They are also hunted regularly: since 2003 a few individuals (1-3) have been culled yearly.

During our survey raccoon Procyon lotor (Linnaeus, 1758) was once observed by a local hunter (Popien, the Rawka river, UTM DC 23). Yet, this information was not confirmed. Nevertheless, according to the data of Experimental Station of Polish Hunting Association in Czempiń, in the season 2006/2007 raccoons were harvested in Łódź voivodship (Okarma \& Tomek 2008), the fact makes its presence in Rogów area conceivable.

Anthropogenic predators (domestic dogs and cats) are, according to the results obtained by spot-light counting on regular routes, most numerous predators. Their density was estimated at 2.4 and 6.1 ind./100 ha, respectively (Krauze 2008).

\section{Cetartiodactyla}

In this order roe deer Capreolus capreolus is definitely most abundant. Its average density calculated per $1 \mathrm{~km}^{2}$ of forest area is from 17 (Gluchów forest) up to 67 ind./100 ha in Jasień forest (Table 4). According to these estimates, total abundance of roe deer in the forest area can be as high as ca. 800 individuals. Yet, it must be taken into account that some individuals, present in the arable lands or in small wood patches, were most probably not recorded during the censuses. According to Pielowski (1999) roe deer densities recorded for Rogów are among the highest in Poland and Europe. Long term study in Górki forest complex proves that density of this species is relatively stable (Fig. 2). The hunting bag of roe deer is relatively low and cannot be treated as an abundance indicator: in the seasons 2003-2009 it was leveled at 21-40 individuals.

Table 4. Spring density and abundance of roe deer in the forest complexes in the vicinity of Rogów provided by drive census (data from the Department of Forest Zoology and Wildlife Management);

*autumn density, **no density estimates were done, mean value for all the other forest complexes adopted

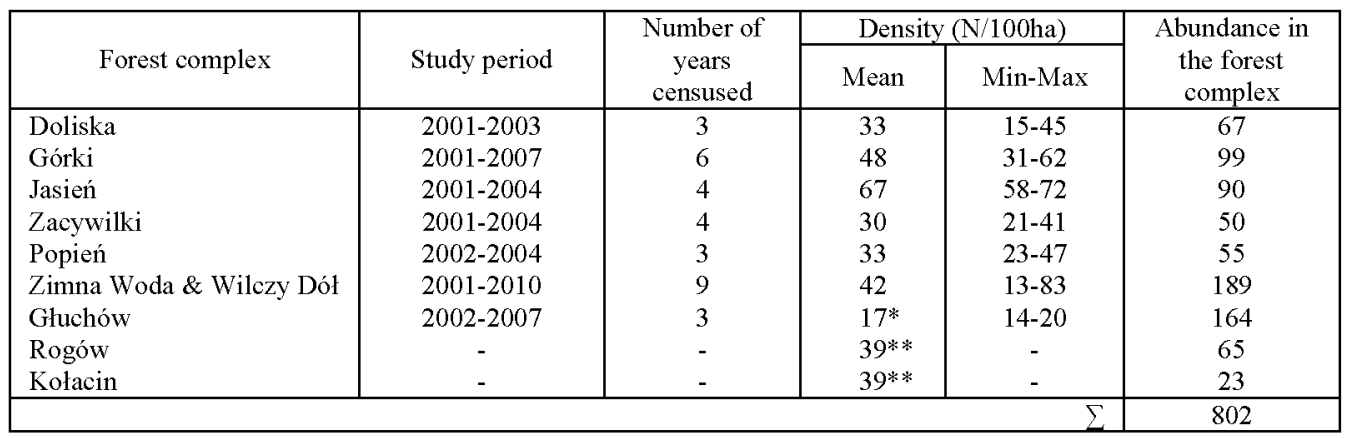


Red deer Cervus elaphus is permanently present in the area. Yet. these days rut does not take place. The main sanctuary is Gluchów forest. However, in other areas. mainly during migration. these animals are also present. Red deer are regularly recorded during drive censuses, i.e. single individual in February 2008 and 2010 (Zimna Woda \& Wilczy Dól) and in autumn 2002 and 2007 (Gluchów). The hunting bag of red deer used to be higher as compared to nowadays. i.e. in 1990-1993 it was between 26-18 individuals. Then it dropped and till 2002 did not exceed 13 (Kowalski 2004). In the last years (2003-2009) no more than 5 animals were harvested annually. This decrease, assumingly being in line with the density fall, can be explained by two reasons. First. the increased red deer culling in Polish forests in the 1990s and second. higher isolation of the population in question from the bigger population in Spala Forest. Area of Rogów is separated from Spala Forest by an express road, which got fenced and became noticeably busier over the last 20 years.

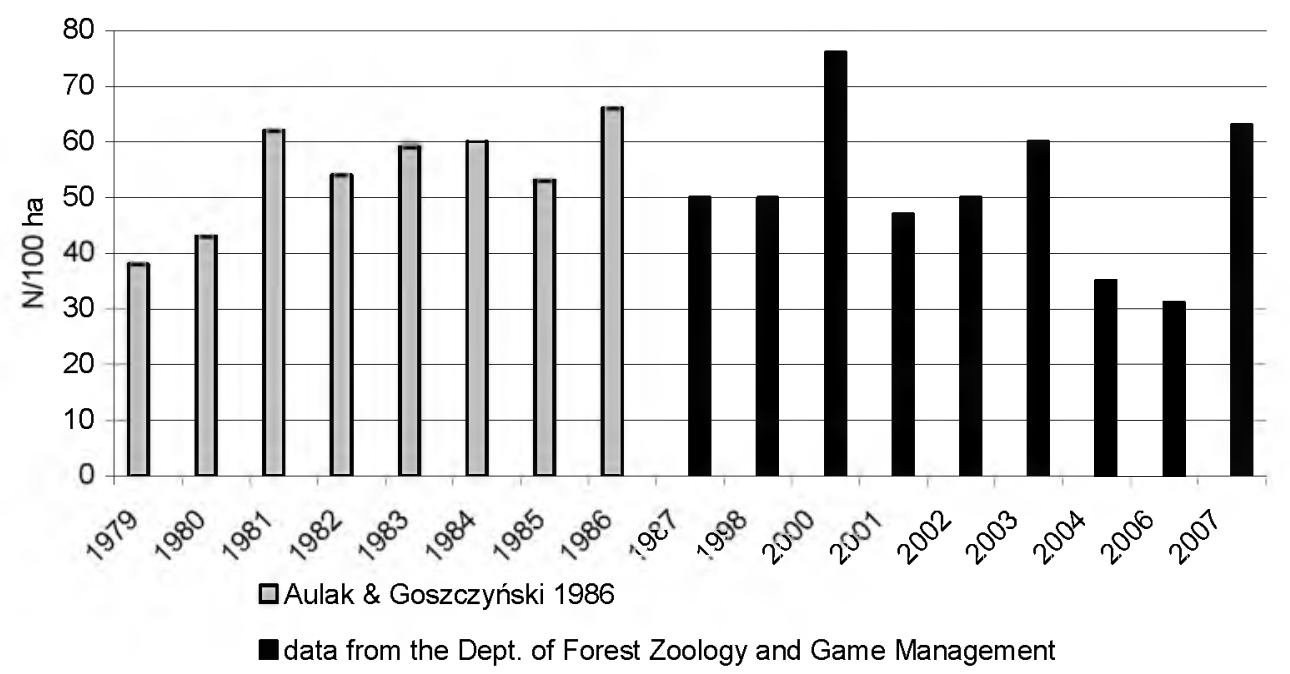

Fig. 2. Changes in spring density of roe deer Capreolus capreolus in Górki forest

Elk Alces alces was first registered in 1981when one $q$ and two juv. were culled (data from the Forest Experimental Station in Rogów). Since 2001 some migrating individuals have been noted regularly, i.e. in 2001 an individual was seen at the Rawka river near Popień forest (information from the employees of Popień farm). in 2003-2004 and between June and July 2009 cows with offspring were present in Gluchów forest, in 2009 one individual was recorded in Jasien forest (D. Dałkowski, G. Kowalski, P. Sowik, pers. comm.). Also, on 23.10.2010 one individual was seen in the north-east part of Gluchów forest (M. Wasilewski. pers. inf.) and in October 2010 one female was killed on a road going through Wilczy Dól forest (two calves escaped) (D. Dałkowski, pers. comm.). Most recently (13.05.2011) tracks were registered in Popień forest (J. Gryz, pers. obs.).

Fallow deer Dama dama is a new species for the area. It was first noted in 2007, when $\delta$ ad. was observed in Zimna Woda \& Wilczy Dól forest (D. Dałkowski, pers. comm.). Then. on 14.01.2008 a group of 9 animals (including 3 stags and does with calves) was introduced into Gluchów forest. The next year further 11 individuals were released (data from the Experimental Forest Station). The animals were bred in captivity in both Poland and Slovakia. In 2009 and 2010 juveniles were observed in Gluchów forest (D. Dalkowski, pers. comm.). 
Nevertheless, fallow deer was not recorded during the last drive census (on 7.10.2009). On 19.04.2011 two more animals of unknown origin (captured in Lódź) were released.

Density of wild boar Sus scrofa is difficult to estimate. According to the authors' observations as well as the information from the Forest Service wild boars are present in all the forest complexes. Numerous groups of boars were recorded during drive censuses: 11 individuals in February 2008 (Zimna Woda \& Wilczy Dól) and 14 individuals in October 2006 (Gluchów). Also, during spot-light count (15.11.2007) a group of 15 animals was recorded in the field to the north of Zimna Woda \& Wilczy Dól forest. In September 2008 a group of wild boars ( $2 \mathrm{ad}$. and 8 juv.) were killed by a train near Zimna Woda \& Wilczy Dól forest and in 2009 three casualties were found on the road crossing Rogów forest. The hunting bag of this species was 10-24 in the years 1990-2002 (Kowalski 2004) and then rose achieving 50-109 ind. in 2003-2009. Most of the animals are harvested in the area of Gluchów forest.

\section{DISCUSSION}

Theriofauna of Rogów can be assumed as relatively rich - mammals registered in the study area constitute more than $50 \%$ of all the mammals present in Poland. The number of species in Rogów is quite comparable or a bit lower than the ones noted for the Kampinos National Park (52 species, www.kampinoski-pn.gov.pl) or the Bialowieża Primeval Forest ( 58 species, Pucek 2001).

Among bats, Leisler's bat is the most valuable species listed in the Polish Red Data Book (Glowaciński 2001). Also, barbastelle is an endangered species on a European scale. Both bats are connected with deciduous and mixed old forest stands, finding suitable habitats in the study area.

The list of bat species that occur in the study area is probably incomplete. Further investigations could possibly reveal the presence of four more species: Natterer's bat Myotis nattereri (Kuhl, 1817), pond bat Myotis dasycneme (Boie, 1825), northern bat Eptesicus nilssonii (Keyserling \& Blasius, 1839), and common pipistrelle Pipistrellus pipistrellus (Schreber, 1774). Moreover, Bechstein's bat Myotis bechsteinii (Kuhl, 1818) presence cannot be excluded as the nearest locality at the edge of its continuous range is located ca. $30 \mathrm{~km}$ south (Fuszara \& Cygan 1994).

Bat assemblages in the vicinity of Rogów, both their species composition and dominant species, are typical for Polish lowland forested landscapes, e.g. Kampinos Forest (Kowalski \& Lesiński 1995). The lack of $M$. nattereri, which is relatively frequent and abundant at many sites (Kowalski \& Lesiński 1994, 1995, Kowalski et al. 2001, Lesiński 2001), seems to be the most notable difference. We expect that in the study area the population of this species is not numerous and therefore it is harder to be found.

We may assume that among rodents all the species were recorded. The closest localities of pygmy field mouse Apodemus uralensis (Pallas, 1811) are ca. 70 (Pucek \& Raczyński 1983) or 90 km (Lesiński 1991) away so its presence in Rogów seems unlikely.

The presence of common dormouse Muscardinus avellanarius (Linnaeus, 1758) appears as more probable as the closest known locality is only $25 \mathrm{~km}$ away. It is in Wólka Łasiecka $\left(52^{\circ} 03^{\prime} 41.26^{\prime} \mathrm{N}, 20^{\circ} 09^{\prime} 15.02^{\prime}\right.$ 'E) where it was found on 10.04 .2009 in the diet of tawny owl ( 1 ind./105 vertebrates, G. Lesiński, unpubl. data). Yet, having in mind that faunistic explorations in the vicinity of Rogów were much more extensive, i.e. 1368 vertebrates identified from tawny owl pellets only by Gryz (2009), we may assume that, with high probability, common dormouse is absent from the area. The most possibly it is extinct due to forest fragmentation. 
The record of common hamster is quite noticeable as it is the most northern, known nowadays, locality of this species in Poland. Obviously, studies on the present and future state of the hamster population in Rogów should be of high priority.

Although rather rich, theriofauna of Rogów contains also considerable number of alien species. Species not indigenous to Poland form $13 \%$ of all mammalian species in Rogów, the figure that is similar to what is stated for Poland in general (Andrzejewski \& Weigle 2003). These are: house mouse and brown rat - species present in Poland historically, muskrat and rabbit that colonised Poland in the second half of XIX and first half of XX century (Okarma \& Tomek 2008), American mink and raccoon dog that entered the mammal list of Rogów later, in the second half of XX century and fallow deer that was intentionally introduced only a few years ago. Moreover, colonization of the area by next species, raccoon, is probably inevitable in the foreseeable future.

Noticeably, anthropogenic predators (domestic dog and cat) are important and numerous predators in the area, cases of their breeding in the wild were recorded (Gryz 2005, Krauze 2008).

\section{ACKNOWLEDGEMENTS}

The authors would like to thank Dariusz Dalkowski, Jacek Goszczyński, Grzegorz Kowalski, Pawel Sowik and Michal Wasilewski for sharing their personal observations. We would like to show our gratitude to Jacek Goszczyński for making his unpublished data available. We would also like to thank to Dariusz Anderwald for giving access to the Museum collection and to Dariusz Dalkowski for the data on game management. Moreover, we are grateful to all the local inhabitants who let us to their settlements: cellars and attics, and who passed their observations on local mammals.

\section{REFERENCES}

ANDRZEJEWSKI R. \& WEIGLE A. (eds) 2003. Różnorodność biologiczna Polski. Narodowa Fundacja Ochrony Środowiska, Warszawa., $284 \mathrm{pp}$.

AULAK W. 1971. Zespoly drobnych kręgowców dna lasu w Nadleśnictwie Rogów. Zeszyty Naukowe SGGW Leśnictwo 16: 109-121.

AULAK W. \& GOSZCZYŃSKI J. 1986. An inventory of hoofed populations driven through entire forest complexes. Wiadomości Ekologiczne 32: 403-413.

Brzezinski M., Romanowski J., CYGAN J. P. \& PABIN B. 1996. Otter Lutra lutra distribution in Poland. Acta Theriologica 41: 113-126.

FuszARA M. \& CYGAN J. P. 1994. Nowe stanowisko nocka Bechsteina, Myotis bechsteini (Kuhl, 1818) w centralnej Polsce. Przegląd Zoologiczny 38: 335-337.

GEOWACIŃSKI Z. (ed.) 2001. Polish Red Data Book of Animals, Vetrebrates. PWRiL Warszawa, 449 pp.

GOSZCZYNSKK J. 1985. Wpływ strukturalnego zróżnicowania krajobrazu ekologicznego na przebieg interakcji drapieżnik-ofiara. Rozprawy Naukowe i Monografie. Wydawnictwo SGGW-AR, Warszawa, 79 pp.

GOSZCZYNSKI J. 1986. Diet of foxes and martens in Central Poland. Acta theriologica 31: 491-506.

GOSZCZYNSKI J. 1991. The food habits of buzzards and goshawks during the nesting period. In: CSANYI S., ERNHAFT J. (eds). XXth Congress of the International Union of Game Biologists, University of Agricultural Sciences, Gödöllö, Hungary, August 21-26, 1991, pp. 387-390. University of Agricultural Sciences, Gödöllö, Hungary, 705 pp.

GoszCZYNSKI J. 1995. Lis. Monografia przyrodniczo-łowiecka. Oikos Oficyna Wydawnicza, Warszawa, 137 pp.

GoszCzyissi J. \& PILATOWSKI T. 1986. Diet of common buzzards (Buteo buteo L.) and goshawks (Accipiter gentilis L.) in the nesting period. Ekologia Polska 34: 655-667.

GOSZCZYNSKI J. \& SKOCZYÍSKA J. 1996. Density estimation, family group size and recruitment in a badger population near Rogów (Central Poland). Miscellània Zoològica 19, 2: 27-33.

GOSZCZYŃSKI J., MISIOROWSKA M. \& JUSZKO S. 2008. Changes in the density and spatial distribution of red fox dens and cub numbers in central Poland following rabies vaccination. Acta Theriologica 58: 121-127.

Goszczyński J., Posluszny M., Pilot M. \& Gralak B. 2007. Patterns of winter locomotion and foraging in two sympatric marten species: Martes martes and Martes foina. Canadian Journal of Zoology 85: 239-249.

GRYZ J. 2003. Ekologia populacji jastrzębia Accipiter gentilis w Lasach Rogowskich. Master's dissertation. Department of Forest Zoology and Game Management. Faculty of Forestry. Warsaw University of Life Sciences, $73 \mathrm{pp}$. 
GRYZ J. 2005. Nocne obserwacje psów Canis familiaris w warunkach mozaiki polno-leśnej w środkowej Polsce. In: HĘDRZAK M. (ed.), Zmiany w populacjach ssaków jako pochodna dynamiki zmian środowiska, p. 102. Akademia Rolnicza w Krakowie, Katedra Hodowli Bydła, Zespół Metod i Organizacji Hodowli Zwierząt Gospodarskich i Wolno Żyjacych, 202 pp.

GRYZ J. 2009. Środowiskowe uwarunkowania składu pokarmu i rozrodu puszczyka Strix aluco Linnaeus 1758. Doctoral dissertation. Department of Forest Zoology and Game Management. Faculty of Forestry. Warsaw University of Life Sciences, $78 \mathrm{pp}$.

GRYZ J. \& KRAUZE D. 2007. Śródleśne populacje polnika Microtus arvalis na terenie Nadleśnictwa Rogów. In: Książka abstraktów X Ogólnopolskiej Konferencji Teriologicznej, 13-14.02.2007 Warszawa, pp. 26-27. Warsaw University of Life Sciences, Warsaw, $77 \mathrm{pp}$.

GRYZ J. \& KRAUZE D. 2007. Long-term decrease of brown hare population in central Poland. In: SJÖBERG K. \& ROOKE T. (eds). Book of Abstracts of the International Union of Game Biologists XXVIII Congress, 11-18 August 2007, Uppsala, Sweden, p. 209. Swedish University of Agricultural Sciences, Uppsala, Sweden, 387 pp.

GRYZ J. \& KRAUZE-GRYZ D. 2011. Wykorzystanie skrzynek lęgowych przez puszczyki w środkowej Polsce. Studia i Materiały Centrum Edukacji Przyrodniczo Leśnej (in press).

JUSZKO S. 2005. Wplyw drapieżnictwa na śmiertelność zająca szaraka w środkowej Polsce. Doctoral dissertation. Department of Forest Zoology and Game Management. Faculty of Forestry. Warsaw University of Life Sciences, 81 pp.

KOBOJEK E. 2005. Environmental effect of the reintroduction of the beaver (Castor fiber) to the Rawka Valley. Geografical Review 77: 383-396.

KOWALSKI G. 2004. Analiza gospodarki łowieckiej w obwodach Leśnego Zakładu Doświadczalnego w Rogowie w latach 1990-2002. Engineer dissertation. Department of Forest Zoology and Game Management. Faculty of Forestry. Warsaw University of Life Sciences, $25 \mathrm{pp}$.

KOWALSKI M. \& LESIŃSKI G. 1994. Bats occupying nest boxes for birds and bats in Poland. Nyctalus (N.F.) 5: 19-26.

KOWALSKI M. \& LESIŃSKI G. 1995. Skład gatunkowy i wybiórczość kryjówek nietoperzy w Puszczy Kampinoskiej. Przegląd Przyrodniczy 6, 2: 99-108.

Kowalski M., Ostrach-Kowalska A., KrasnodęBski I., SACHANowicz K., Ignaczak M. \& RUSIN A. 2001. Nietoperze Parków Krajobrazowych: Górznieńsko-Lidzbarskiego i Welskiego. Nietoperze 2: 117-124.

KRAUZE D. 2003. Ekologia populacji myszołowa Buteo buteo (Linnaeus, 1758) w lasach Rogowskich (środkowa Polska). Master's dissertation. Department of Forest Zoology and Game Management. Faculty of Forestry. Warsaw University of Life Sciences, $63 \mathrm{pp}$.

KRAUZE D. 2008. Biocenotyczna rola kota domowego Felis silvestris f. catus w różnych wariantach mozaiki polnoleśnej. Doctoral dissertation. Department of Forest Zoology and Game Management. Faculty of Forestry. Warsaw University of Life Sciences, 92 pp.

KRAUZE D., GRYZ J. \& GOSZCZYŃSKI J. 2005. Food composition of the goshawk (Accipiter gentilis L. 1758) during the nesting season in the Rogów Forest (Central Poland). Folia Forestalia Polonica (A) 47: 45-53.

KURZYNA M. 1982. Zmiany liczebności i składu zespołu drobnych ssaków w cyklu rocznym w uroczysku Górki. Master's dissertation. Department of Forest Zoology and Game Management. Faculty of Forestry. Warsaw University of Life Sciences, 55 pp.

LESIŃSKI G. 1991. Skład pokarmu płomykówki, Tyto alba (Scop.) na Wyżynie Wieluńskiej. Lubelski Przegląd Przyrodniczy 2, 4: 29-35.

LESIŃSKI G. 2001. Nietoperze Chiroptera Kotliny Biebrzańskiej i terenów przyległych. Parki Narodowe i Rezerwaty Przyrody 20, 2: 51-64.

LESINSKI G., GRYZ J. \& KRAUZE D. 2009. [Bats as road kills in the vicinity of Rogow (Lodz voivodship)]. Nietoperze 10: $70-72$.

OKARMA H. \& TOMEK A. 2008. Lowiectwo. Wydawnictwo Edukacyjno-Naukowe $\mathrm{H}_{2} \mathrm{O}$, Kraków. 503 pp.

OSOWIECKA K. 2008. Ocena różnorodności gatunkowej ssaków na terenie Leśnego Zakładu Doświadczalnego w Rogowie. Master's dissertation. Department of Forest Zoology and Game Management. Faculty of Forestry. Warsaw University of Life Sciences, $59 \mathrm{pp}$.

PIELOWSKI Z. 1999. Sarna. Oficyna Edytorska „Wydawnictwo Świat”, Warszawa, 142 pp.

PosetszNY M. 2005. Skład pożywienia i wykorzystanie areału przez kuny w LZD Rogów. Doctoral dissertation. Department of Forest Zoology and Game Management. Faculty of Forestry. Warsaw University of Life Sciences, $60 \mathrm{pp}$.

PUCEK Z. 2001. Mammalia - ssaki. In: GUTOWSKI J. \& JAROSZEWICZ B. (eds), Katalog fauny Puszczy Białowieskiej Instytut Badawczy Leśnictwa, Warszawa, $403 \mathrm{pp}$.

PUCEK Z. \& RACZYŃSKI J. (eds) 1983. Atlas of Polish mammals. PWN - Polish Scientific Publishers, Warsaw, 188 pp.

SMITH R.K., JENNINGS N.V. \& HARRIS S. 2005. A quantitative analysis of the abundance and demography of European hares Lepus europaeus in relation to habitat type, intensity of agriculture and climate. Mammal Review 35: 1-24.

TWARDOWsKi T. 1988. Wyniki introdukcji bobra Castor fiber L. w województwie skierniewickim. Master's dissertation. Department of Forest Zoology and Game Management. Faculty of Forestry. Warsaw University of Life Sciences, 55 pp. 
ZARĘBA R. 1993. Zarys historii lasów. In: ZIELONY R. (ed.), Warunki przyrodnicze lasów doświadczalnych SGGW w Rogowie, pp. 16-23. Wydawnictwo SGGW, Warszawa, $301 \mathrm{pp}$.

ZIELONY R. (ed.) 1993. Warunki przyrodnicze lasów doświadczalnych SGGW w Rogowie. Wydawnictwo SGGW, Warszawa, $301 \mathrm{pp}$.

ZIOMEK J. \& BANASZEK A. 2007. The common hamster, Cricetus cricetus in Poland: status and current range. Folia Zoologica 56: 235-242.

\section{STRESZCZENIE}

\section{[Ssaki okolic Rogowa (środkowa Polska]}

Celem pracy byla inwentaryzacja teriofauny okolic Rogowa. W latach 2000-2011 zastosowano większość dostępnych metod inwentaryzacji ssaków, m.in. odłowy w pułapki żywołowne, analizy wypluwek czy tropienia. Dokonano przeglądu dostępnych danych literaturowych oraz danych niepublikowanych. Wykorzystano również eksponaty zgromadzone w Muzeum Lasu i Drewna w Rogowie. Stwierdzono występowanie 51 dziko żyjąych gatunków ssaków z 7 rzędów, w tym 7 gatunków nierodzimych (piżmak, szczur wędrowny, mysz domowa, królik, norka amerykańska, jenot, daniel). Oprócz tego odnotowano występowanie dwóch gatunków drapieżników antropogenicznych (kota i psa). W wybranych przypadkach dokonano analizy trendów liczebności: liczebność zająca, królika, chomika czy jelenia spadała, natomiast bobra, dzika, lisa i jenota wyraźnie wzrosla. W XXI w. potwierdzono obecność jednego gatunku z Polskiej Czerwonej Księgi Zwierząt (borowiaczka). Istotnym było również stwierdzenie występowania chomika europejskiego na najdalej wysuniętym na pólnoc znanym obecnie w Polsce stanowisku. 